\title{
Use of Evidence-Based Teaching Practice in Dental Education
}

\author{
Shibani Sahni and Sang E Park* \\ Associate Dean for Dental Education, Harvard School of Dental Medicine, USA
}

Submission: May 28, 2021; Published: June 07, 2021

*Corresponding author: Sang E Park, Associate Dean for Dental Education, Harvard School of Dental Medicine, Boston, Massachusetts, USA

\begin{abstract}
Educational practices that stem from an evidence-based approach believe in principles of teaching and learning grounded in scientific evidence. Evidence-based education could promote development of research and scholarship and contribute to the evaluation and application of scientific research. The relationship between evidence-based dental education and the skills and knowledge needed for educational practice could be an important one. Dental education could benefit from including evidence-based teaching practices that embody decision making and critical thinking skills by taking an evidence-based approach. Active incorporation of educational research in the principles of teaching and learning could provide a foundation for curriculum development and design in dental education.
\end{abstract}

Keywords: Dental education; Critical thinking; Educational research; Curriculum development

\section{Introduction}

Evidence-based dentistry is understood to lead to improvement in delivering oral health care, and to advance critical thinking and lifelong learning skills. An evidence-based approach to patient care and clinical decision making could provide clinicians with the ability to embrace complex problems, to engage and solve them critically, and thereby to improve overall patient care [1-3]. However, educators do not have a widespread culture of using research to inform their teaching decisions with best evidence. The use of an evidence-based approach to education has not been explored extensively. Curriculum design, student assessments, and program evaluations are areas in which evidence-based teaching and learning can be further developed and utilized. An evidence-based curriculum has the concept of using the evidencebased approach for educational teaching practice, evaluation of student performance and assessments of the programs that align with the curriculum [1]. The practice of measuring and applying evidential studies could be used to evaluate decisions as new skills are developed to identify and resolve questions.

Advances in technology have driven new pedagogical methods and changed the way students learn, and the ways of teaching those skills are changing rapidly. Multifaceted approaches to promote evidence-based education and practice using technology such as virtual platforms, electronic devices and online materials are on the rise [4]. The increased availability of information has also led to an increase in the importance of evidence-based dental education; students must be able to think critically and determine whether the information they are receiving is accurate. Therefore, faculty must be able to demonstrate and teach critical thinking skills. The curriculum design for providing evidencebased learning is critical as educational methodologies evolve; however, assessment strategies for progression towards evidencebased education are limited due to the complexity associated with evaluation [5-7]. Teaching strategies that incorporate critical appraisal of scientific research for evidence-based applications could be implemented in the curriculum.

One path to achieving an evidence-based approach to dental education is training current and future educators to engage in opportunities to integrate evidence-based teaching and learning into the curriculum. Faculty development efforts are critical factors as critical thinking and analysis and research evidence are incorporated in educational decisions. Faculty understanding of research evidence as well as recognition of the strengths and limitations of evidence can be used instead of mainly relying on habitual teaching experiences. Development of faculty training programs could be a potential starting point for evidence-based teaching practice research, and an important component in addition to assessments of the objectives and effectiveness of teaching programs $[8,9]$. It is also important to teach evidence- 
based teaching practice to students, in addition to the faculty, by offering opportunities for students to learn about evidencebased education. The principles of an evidence-based approach to learning can be applied across multiple areas of the curriculum so that the members of the learning community are embedded with a culture of evidence-based approach to education. Students could participate in collaborations to achieve the best outcome for their own learning as they are essential constituents in promoting evidence-based educational practice in the future.

\section{Conclusion}

Dental education could consider actively embracing an evidence-based approach and establishing a purposeful direction for educational research, thus providing a set of principles and practices for teaching and learning applied in scientific evidence. Educational research and scholarship are critical to have sustained improvements in using evidence-based teaching practices and thus improving quality of education provided.

\section{References}

1. Winning T, Needleman I, Rohlin M, Carrassi A, Chadwick B, et al. (2008) Evidence-based care and the curriculum. Eur J Dent Educ 12(s1): 4863.

2. Hong B, Plugge E (2017) Critical appraisal skills teaching in UK dental schools. Brit Dent J 222(3): 209-213.
3. Innes N, Hurst D (2012) GDC learning outcomes for the undergraduate dental curriculum. Evid Based Dent 13: 2-3.

4. Kyriakoulis K, Patelarou A, Laliotis A, Wan AC, Matalliotakis M, et al. (2016) Educational strategies for teaching evidence-based practice to undergraduate health students: Systematic review. J Educ Eval Health Prof 22(13): 34

5. Guyatt G, Cairns J, Churchill D, Cook D, Haynes B, et al. (1992) Evidencebased medicine: A new approach to teaching the practice of medicine. JAMA 268(17): 2420-2425.

6. Horntvedt MT, Nordsteien A, Fermann T, Severinsson E (2018) Strategies for teaching evidence-based practice in nursing education: A thematic literature review. BMC Med Educ 18(1): 172.

7. Marshall TA, McKernan SC, Morarend CLS, Armstrong SG, Marchini L, et al. (2018) Evidence-based dentistry skill acquisition by second-year dental students. Eur J Dent Educ 22(3): e612-e618.

8. Marshall TA, Morarend CLS, Armstrong SG, McKernana C, Marchini L, et al. (2017) An approach on defining competency in evidence-based dentistry. Eur J Dent Educ 22 (1): e107-e115.

9. Weyant Rj (2019) Teaching evidence-based practice: Considerations for dental education. Dent Clin North Am 63(1): 97-117.

10. Rugh JD, Hendricson WD, Glass BJ, Hatch JP, Deahl ST, et al. (2011) Teaching evidence-based practice at the University of Texas Health Science Center at San Antonio dental school. Tex Dent J 128(2): 187 190.

\section{Your next submission with Juniper Publishers} will reach you the below assets

- Quality Editorial service

- Swift Peer Review

- Reprints availability

- E-prints Service

- Manuscript Podcast for convenient understanding

- Global attainment for your research

- Manuscript accessibility in different formats

( Pdf, E-pub, Full Text, Audio)

- Unceasing customer service

Track the below URL for one-step submission https://juniperpublishers.com/online-submission.php 